\title{
PENGARUH SUBTITUSI LUMPUR SIDOARJO (LUSI) TERHADAP KUAT TEKAN BATA BETON (PAVING BLOCK)
}

\author{
Masbuhin ${ }^{1}$

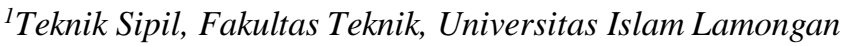 \\ Jl. Veteran No. 53A Lamongan \\ 0322-324706 \\ E-mail: masbuhinmn@gmail.com
}

\begin{abstract}
This study aims to determine the process of utilizing Sidoarjo Mud (LUSI) as a substitute for paving blocks and to determine the results of the compressive strength test of using LUSI as a substitute for paving blocks. The LUSI substitution is expected to be able to provide innovations in the construction of a paving block mixture. The research method used is the experimental method. The manufacture of test objects starts from the preparation stage, mix design, manufacture of test objects, testing and classifying paving blocks according to SNI 03-0691-1996. The sample of specimens used normal mix design and mix design substitute LUSI 40\% of the fine aggregate value. Based on the results of research, paving blocks with a normal mix design of 1Pc: 2Ps are classified as quality A, 1Pc: 3Ps and 1Pc: 4Ps are classified as B quality, while for paving blocks substituting LUSI in a mixture of $1 P c: 2 P$ s is classified as quality B, for a mixture of 1Pc: $3 P s$ and $1 P c: 4 P s$ is classified as $C$ quality. It can be concluded that the compressive strength of paving blocks has decreased in compressive strength after being substituted by LUSI, with a successive percentage value of 32\%, 59\% and 58\%.
\end{abstract}

Keywords: LUSI, Paving Block, Compressive Strength

\section{PENDAHULUAN}

Bencana alam merupakan salah satu faktor penyebab terjadinya kerusakan lingkungan hidup. Kerusakan lingkungan hidup berdampak buruk terhadap aktifitas di lingkungan sekitar yang berpengaruh langsung terhadap kondisi fisik maupun aktifitas sosial dan ekonomi.

Pada tahun 2006 terjadi bencana di Kecamatan Porong Kabupaten Sidoarjo. Bencana ini lebih dikenal dengan sebutan Semburan Lumpur Lapindo atau Lumpur Sidoarjo (LUSI). Upaya penganggulangan semburan LUSI sudah dilakukan dengan beberapa kali skenario pengehentian, hanya saja sampai saat ini belum berhasil menghentikan semburan tersebut.

Bencana alam di Indonesia bukan hanya bencana semburan LUSI saja, bencana lainnya juga sering kita jumpai di Indonesia, seperti halnya banjir. Bencana banjir merupakan permasalahan yang harus dihadapi sebagian kota-kota besar. Penggunaan aspal yang masih dominan digunakan di jalan-jalan yang bertonase rendah, seperti halnya di jalan-jalan Desa, perumahan dan halaman gedung di instansiinstansi juga masih dominan menggunakan perkerasan aspal, yang mana penggunaan aspal dapat mempengaruhi daya resap air hujan.

Perkembangan penggunaan beton saat ini bukan hanya digunakan pada konstruksi gedung saja, untuk saat ini beton sudah dikembangkan sebagai perkerasan kaku (Rigit Pavement), dalam perkembangan perkerasan kaku ini telah banyak digunakan sebagai bahan perkerasan jalan raya, antara lain perkerasan kaku dengan menggunakan campuran beton bertulang atau menggunakan beton terkunci seperti Paving Block dan lain-lain.

Inovasi-inovasi dalam bidang pembangunan saat ini diperlukan untuk kemajuan pembangunan, salah satunya adalah dengan inovasi perkerasan pada jalan, yang dalam hal ini menggunakan LUSI sebagai subtitusi agregat halus dalam pembuatan bata beton (Paving Block). Paving Block dengan inovasi ini diharapkan semakin banyak digunakan sebagai pengganti aspal, karena mudah dipasang dan tidak memerlukan alat berat serta dapat diproduksi secara massal, pemeliharaan mudah karean bisa dipasang dan dibongkar kembali.

Paving Block merupakan material terbuat dari bahan-bahan yang tergolong dari Sumber Daya Alam yang tidak bisa diperbarui. Penggunaan bahan yang dilakukan secara terus menerus sebagai bahan konstruksi berdampak pada kerusakan alam. Hal tersebut mendorong ditemukannya inovasi-inovasi material alternatif sebagai subtitusi bahan pembuatan paving block.

Berdasarkan uraian latar belakang diatas, permasalahan yang akan dikaji dalam penelitian ini yaitu:

(a) Bagaimana proses awal hingga akhir pemanfaatan LUSI sebagai subtitusi agregat halus dalam pembuatan paving block?

(b) Bagaimana hasil uji kuat tekan pemanfaatan LUSI sebagai subtitusi agregat halus dalam pembuatan paving block?

Berdasarkan rumusan-rumusan masalah di atas, maka tujuan penelitian ini adalah sebagai berikut: 
(a) Untuk mengetahui proses awal hingga akhir pemanfaatan LUSI sebagai subtitusi agregat halus dalam pembuatan paving block.

(b) Untuk mengetahui hasil uji kuat tekan pemanfatan LUSI sebagai subtitusi agregat halus dalam pembuatan paving block.

Beton adalah campuran antara semen Portland atau semen hidraulik lainnya, agregat halus, agregat kasar dan air, dengan atau tanpa bahan tambahan yang membentuk masa padat (SNI 03-2847-2002).

Beton merupakan campuran dari beberapa bahan, antara lain agregat kasar dan agregat halus. Agregat halus yang digunakan biasanya adalah pasir alam maupun pasir yang dihasilkan oleh industri pemecah batu, sedangkan agregat kasar yang dipakai biasanya berupa batu alam maupun batuan yang dihasilkan oleh industri pemecah batu. Beton merupakan salah satu bahan konstruksi yang telah umum digunakan untuk bangunan gedung, jembatan, jalan, bendungan dan lain-lain.

Menurut Asroni (2010:2), Secara sederhana beton dibentuk oleh pengerasan campuran antara semen, air, agregat halus (pasir) dan agregat kasar (batu pecah atau kerikil), kadang-kadang ditembahkan campuran dari bahan lain seperti admixture untuk memperbaiki atau menambah kuat tekan dari kualitas beton.

Bata beton (Paving Block) adalah suatu komposisi bahan bangunan yang dibuat dari campuran semen portland atau bahan perekat hidrolis sejenisnya, air dan agregat dengan atau tanpa bahan tambahan lainnya yang tidak mengurangi mutu bata beton tersebut (SNI-03-06911996).

Paving block biasanya terdiri dari campuran semen, agregat dan air, sehingga memiliki karakteristik yang hampir mendekati mortar. Diluar negeri istilah paving block dibagi menjadi dua jenis, pertama concrete block yang disini dikenal dengan conblock. Kedua adalah clay pavers/ clay block/ clay bricks block yang ada di pasaran.

Selain sebagai penutup permukaan tanah dan peresapan air, paving block merupakan alternatif baru sebagai sistem perkerasan. Kekuatan paving block yang terpasang di atas permukaan tanah ditentukan oleh dua hal, yaitu:

(a) Kuat tekan masing-masing elemen paving block yang terbuat dari beton dengan mutu tertentu.

(b) Gesekan antar elemen paving block yang dapat terjadi dengan adanya pasir sebagai bahan pengisi diantara sela-sela paving block.

Ada beberapa faktor yang mempengaruhi kekuatan serta mutu dari paving block. Pradana (2019:19) menyebutkan terdapat beberapa faktor yang mempengaruhi kekuatan serta mutu dari paving block yaitu kekuatan beton tergantung pada perbandingan adukan dan disesuaikan dengan kebutuhan pekerjaan.

Dalam SNI-03-0691-1996, dijelakan bahwah syarat mutu bata beton adalah sebagai berikut: (a) Sifat Tampak

Bata beton harus mempunyai permukaan yang rata, tidak terdapat retak-retak dan cacat, bagian sudut dan rusuknya tidak mudah direpihkan dengan kekuatan jari tangan.

(b) Dimensi/ Ukuran

Bata beton harus mempunyai ukuran minimum $60 \mathrm{~mm}$ dengan toleransi $+8 \%$.

(c) Sifat Fisika

Bata beton harus mempunyai sifat-sifat fisika seperti tabel dibawah ini.

Tabel 1. Sifat-sifat Fisika Bata Beton (Paving Block)

\begin{tabular}{cccccc}
\hline \multirow{2}{*}{ Mutu } & \multicolumn{2}{c}{$\begin{array}{c}\text { Kuat Tekan } \\
(\text { MPa })\end{array}$} & $\begin{array}{c}\text { Ketahanan Aus } \\
(\text { mm/menit })\end{array}$ & $\begin{array}{c}\text { Penyerapan } \\
\text { Air Rata-rata } \\
\text { Maks. }\end{array}$ \\
\cline { 2 - 6 } & $\begin{array}{c}\text { Rata- } \\
\text { rata }\end{array}$ & Min & $\begin{array}{c}\text { Rata- } \\
\text { rata }\end{array}$ & Min & $(\%)$ \\
\hline A & 40 & 35 & 0,090 & 0,103 & 3 \\
B & 20 & 17,0 & 0,130 & 0,149 & 6 \\
C & 15 & 12,5 & 0,160 & 0,184 & 8 \\
D & 10 & 8,5 & 0,219 & 0,251 & 10 \\
\hline
\end{tabular}

Sumber: SNI 03-0691-1996

(d) Ketahanan Terhadap Natrium Sulfat

Bata beton (paving block) apabila diuji tidak boleh cacat dan kehilangan berat yang diperkenankan maksimum $1 \%$.

Klasifikasi paving block yang dijelaskan pada SNI-03-0691-1996, adalah sebagai berikut:

(a) Klasifikasi berdasarkan kegunaan dibedakan menjadi 4 klasifikasi paving block. Paving block mutu A digunakan untuk jalan, Paving block mutu B digunakan untuk peralatan parkir, Paving block mutu C digunakan untuk pejalan kaki, Paving block mutu D digunakan untuk taman dan penggunaan lain.

(b) Klasifikasi berdasarkan cara pembuatan dibedakan menjadi 3, yaitu: Paving block press manual atau menggunakan tangan. Paving block press mesin vibrasi/ getar dan yang terakhir adalah paving block press mesin hidrolik.

(c) Klasifikasi berdasarkan bentuk, secara garis besar paving block dibagi menjadi 2, yaitu paving block berbentuk segi empat dan paving block berbentuk segi banyak yang terdiri dari hexagon (segi enam), cacing, grass block, uskup, antik dan thirex).

Lumpur Sidoarjo adalah lumpur panas yang menyembur keluar pada saat pengeboran minyak di Dusun Balongnongo Desa Renokenongo, Kecamatan Porong, Kabupaten Sidoarjo, Jawa Timur, sejak tanggal 29 Mei 2006. Volume lumpur yang keluar rata-rata mencapai $\pm 100.000 \mathrm{~m}^{3} /$ hari, namun akhir-akhir ini diperkirakan volume lumpur yang keluar sebesar 25.000-50.000 m³/hari (Badan Penanggulangan Lumpur Sidoarjo tahun 2012). Rencana induk penanganan Lumpur Sidoarjo yang dikeluarkan oleh Badan Penanggulangan Lumpur Sidoarjo menyebutkan prinsip kesatuan penanganan 
Lumpur Sidoarjo yang harus memperhatikan tata kelola lingkungan, diantaranya adalah reduce, reuse, recycle, repair dan renewable. Pemanfaatan kembali (reuce) material mentah yang melimpah yaitu Lumpur Sidoarjo menjadi material lain yang lebih bermanfaat dan memiliki nilai ekonomi dapat dijadikan salah satu alternatif penanganan dampak semburan Lumpur Sidoarjo. Kapasitas waduk penampung Lumpur Sidoarjo yang dibangun oleh BPLS memiliki kapasitas 54 juta $\mathrm{m}^{3}$, sehingga potensi Lumpur Sidoarjo untuk dimanfaatkan sangat besar (Sugiharto dan Lasino, 2018).

Mineral yang dikeluarkan dari semburan Lumpur Sidoarjo memiliki sifat-sifat fisis berbentuk butiran halus, berwarna abu-abu kehitaman, sangat plastis dan memiliki nilai susut kering tinggi, unsur kimia yang terkandung didominasi oleh silika (>50\%) aluminia (26\%) dan magnesium dengan jumlah relatif kecil (Sugiarto dan Lasino, 2018).

Berdasarkan dari hasil pengujian yang dilakukan oleh Depudi Bidang TPSA-BPPT, lumpur lapindo mempunyai kandungan mineral serta kimia yang baik untuk pembuatan keramik dan bahan bangunan yang berbahan dasar semen karena lumpur Sidoarjo dinilai memiliki kandungan silika yang tinggi. Pengujian toksikologi di 3 laboratorium terakreditasi (Sucofindo, Corelab, Bogorlab) diperoleh kesimpulan bahwa lumpur Sidoarjo tidak termasuk limbah B3 baik untuk bahan anorganik seperti Arsen, Barium, Boron, Timbal, Raksa, Sianida Bebas dan sebagainya, maupun bahan organik seperti, Trichlorophenol, Chlordane, Chlorobenzene, Chloroform dan sebagainya.

Tabel 2. Komposisi Lumpur Sidoarjo

\begin{tabular}{ccc}
\hline No & Komponen & Komposisi $(\%)$ \\
\hline 1 & $\mathrm{SiO} 2$ & 53,08 \\
2 & $\mathrm{AI} 2 \mathrm{O} 3$ & 18,27 \\
3 & $\mathrm{Fe} 2 \mathrm{O} 3$ & 5,60 \\
4 & $\mathrm{CaO}$ & 2,07 \\
5 & $\mathrm{Na} 2 \mathrm{O}$ & 2,97 \\
6 & $\mathrm{~K} 2 \mathrm{O}$ & 1,44 \\
7 & $\mathrm{TiO} 2$ & 0,57 \\
8 & $\mathrm{MgO}$ & 2,89 \\
9 & $\mathrm{SO} 2$ & 2,96 \\
10 & $\mathrm{LOI}$ & 10,15 \\
\hline Sumber: Ekaputri Januarti (2014)
\end{tabular}

Menurut Lasino (2016), LUSI bisa digunakan sebagai bahan bangunan, yang mana pada LUSI terdapat sifat fisis dan mekanis, serta unsur kimia.

(a) Sifat Fisis dan Mekanis

Berikut ini adalah hasil pemeriksaan sifat fisismekanis.

Tabel 3. Hasil Pengujian Sifat Fisis dan Mekanis

\begin{tabular}{clccc}
\hline No & \multicolumn{1}{c}{ Uraian } & Hasil & Syarat & Ket \\
\cline { 2 - 4 } 1 & Plastisitas & & - & - \\
\cline { 2 - 4 } & $\begin{array}{l}\text { Batas Cair } \\
\text { (LL)...........\% }\end{array}$ & 65,50 & - & -
\end{tabular}

\begin{tabular}{|c|c|c|c|c|}
\hline & $\begin{array}{l}\text { Batas Plastis } \\
(\mathrm{PL}) \ldots \ldots \ldots \ldots . . . \%\end{array}$ & 28,10 & - & - \\
\hline & $\begin{array}{l}\text { Indeks Plastis } \\
\text { (IP................. \% }\end{array}$ & 37,40 & $<30,00$ & $\begin{array}{l}\text { Sangat } \\
\text { Plastis }\end{array}$ \\
\hline 2 & Klasifikasi & $\mathrm{CH}$ & - & $\begin{array}{l}\text { Lanau } \\
\text { Plastis }\end{array}$ \\
\hline 3 & $\begin{array}{l}\text { Berat Isi } \\
\text { Basah }\left(\mathrm{g} / \mathrm{cm}^{3}\right)\end{array}$ & 1,79 & - & - \\
\hline
\end{tabular}

(b) Unsur Kimia

Tabel 4. Hasil Analisis Kimia

\begin{tabular}{cccc}
\hline No & Unsur & Hasil Uji $(\%)$ & Syarat \\
\hline 1 & $\mathrm{SiO} 2$ & 52,79 & $50-70$ \\
2 & $\mathrm{~A} 1203$ & 26,35 & $10-35$ \\
3 & $\mathrm{Fe} 203$ & 8,51 & $2-8$ \\
4 & $\mathrm{CaO}$ & 1,97 & $0,5-15$ \\
5 & $\mathrm{MgO}$ & 2,53 & $0,2-5$ \\
6 & $\mathrm{~K} 2 \mathrm{O}$ & 2,86 & - \\
7 & $\mathrm{Na} 2 \mathrm{O} 3$ & 2,08 & - \\
8 & $\mathrm{SO} 3$ & 0,98 & $0-0,5$ \\
9 & $\mathrm{HP}$ & 1,92 & $3-12$ \\
\hline
\end{tabular}

Sumber: Lasino (2016)

\section{METODE}

Metode yang digunakan pada penelitian ini adalah metode eksperimen, dalam penelitian ini secara umum terdapat beberapa tahapan, yang dimulai dengan tahap persiapan, tahap pemilihan variabel pengukuran, pengumpulan data, analisis data dan tahap penarikan kesimpulan.

Parameter yang diuji dalam pengupulan data adalah uji kuat tekan, dimana benda uji ditekan menggunakan alat (Universal Testing Machine) dan pengujian benda uji dilakukan pada saat berumur 7 hari yang kemudain nanti akan dikonversi ke 28 hari.

Populasi dalam penelitian ini adalah Job Mix formula campuran bata beton segar yang dilihat terhadap nilai-nilai hasil uji kuat tekan yang meliputi stabilitas, keawetan atau ketahanan dan kemudahan dalam pelaksanaan.

Sampel pada penelitian ini menggunakan sampel dari populasi, dikarekanan jumlah populasi bersifat data hasil pengujian di laboratorium. Sampel penelitian ini meliputi bahan campuran bata beton normal campuran bata beton dengan subtitusi LUSI $40 \%$, dengan masing-masing kombinasi campuran 1Pc:2Ps, 1Pc:3Ps dan 1Pc:4Ps yang masing-masing sebanyak 4 buah benda uji pada setiap mix design.

\section{HASIL DAN PEMBAHASAN}

3.1 Proses Pemanfaatan LUSI

Penggunaan LUSI sebagai subtitusi agregat halus dalam penggunaan bata beton (Paving Block) dilakukan melalui beberapa tahap, yaitu:

(a) Tahap Pengambilan Bahan LUSI

Tahap ini merupakan tahap awal dari pemanfaatan LUSI, yang mana pada penelitian ini sampel bahan diambil langsung dari tempat 
penampungan semburan, yaitu di sekitar area semburan lumpur dengan jarak pengambilan sampel bahan \pm 300 meter dari pusat semburan LUSI.

(b) Tahap Pengeringan LUSI

LUSI yang telah diambil dalam keadaan basah, maka setelah dilakukan pengeringan dengan cara dijemur di bawah sinar matahari sampai kering.

\subsection{Analisa Bahan}

(a) Pengujian Semen

Penelitian ini menggunakan semen Gresik (Semen Indonesia) sebagai bahan pengikat dari campuran paving block

Tabel 5. Konsistensi Normal Semen Portland

\begin{tabular}{lcc}
\hline \multicolumn{1}{c}{ Percobaan Nomor } & $I$ & $I I$ \\
\hline Berat Semen $(\mathrm{gr})$ & $250 \mathrm{gr}$ & $250 \mathrm{gr}$ \\
Berat Air $(\mathrm{ml})$ & 70 & 67,5 \\
Penurunan $(\mathrm{mm})$ & 8 & 15 \\
Konsistensi & $28 \%$ & $32 \%$ \\
\hline
\end{tabular}

Sumber: Hasil Penelitian, (2020)

Menurut ASTM 187-89 kadar air dalam semen yang baik adalah ketika terjadi penurunan $10 \mathrm{~mm}$.

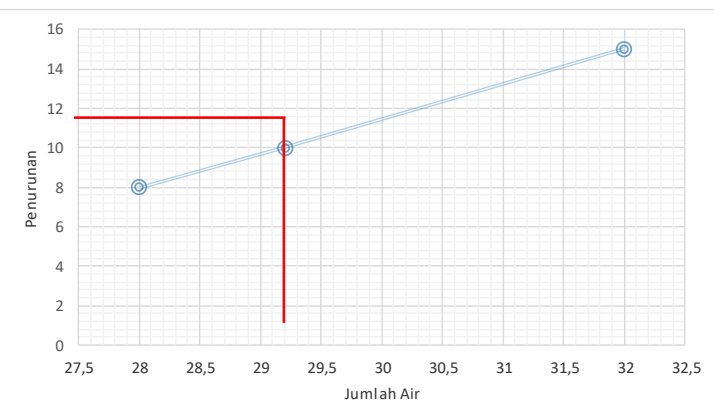

Gambar 1. Grafik Prosentasi Air dengan Penurunan Jarum Vicat

Sumber: Hasil Penelitian, (2020)

Dari hasil pembacaan grafik di atas, maka dapat ditarik kesimpulan bahwah untuk penuruan $10 \mathrm{~mm}$ dibutuhkan air sebanyak 29,2\%.

(b) Pengujian Penurunan Semen Portland

Pengujian ikat semen digunakan untuk mengetahui lama waktu yang diperlukan oleh semen agar nanti menghasilkan campuran yang dapat mengikat dengan baik.

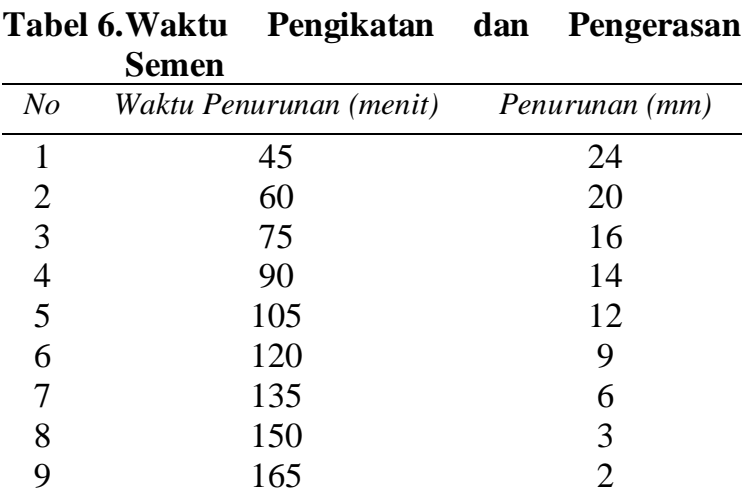

\begin{tabular}{ccc}
\hline No & Waktu Penurunan (menit) & Penurunan $(\mathrm{mm})$ \\
\hline 10 & 180 & 1,5 \\
11 & 195 & 1 \\
12 & 210 & 0,5 \\
13 & 225 & 0 \\
\hline
\end{tabular}

Sumber: Hasil Penelitian, (2020)

(c) Pengujian Berat Jenis Semen

Tabel 7. Berat Jenis Semen

\begin{tabular}{lcc}
\hline \multicolumn{1}{c}{ Percobaan Nomor } & $I$ & $I I$ \\
\hline Berat Semen (w1) - (gr) & $250 \mathrm{gr}$ & $250 \mathrm{gr}$ \\
Berat Semen + minyak + Labu & 548 & 550 \\
Takar (w2) - (gr) & 364 & 365 \\
Berat Labu Takar + Minyak & 3,03 & 3,03 \\
Bj + 0,8 w1 / (w1 + w3 - w2) &
\end{tabular}

Sumber: Hasil Penelitian, (2020)

Dari hasil pengujian berat jenis semen, nilai rata-rata yang didapatkan yaitu sebesar 3,05 $\mathrm{gr} / \mathrm{cm}^{3}$. Berdasarkan ASTM C 188-95 berat jenis semen portland mempunyai besaran antara 3,0$3,2 \mathrm{gr} / \mathrm{cm}^{3}$.

(d) Pengujian Analisa Saringan Distribusi Ukuran Butir/Gradasi Pasir

Tabel 8. Hasil Uji Ayakan Pasir

\begin{tabular}{|c|c|c|c|c|c|}
\hline \multicolumn{2}{|c|}{ Saringan } & \multicolumn{2}{|c|}{ Tertinggal } & \multirow{2}{*}{$\begin{array}{l}\text { \%omulatif } \\
\text { Tertinggal }\end{array}$} & \multirow{2}{*}{$\begin{array}{l}\text { Lolos } \\
\%\end{array}$} \\
\hline $\mathrm{No}$ & $\mathrm{mm}$ & Gram & $\%$ & & \\
\hline 4 & 4,75 & 40 & 4,10 & 4,10 & 95,90 \\
\hline 8 & 2,36 & 50 & 5,13 & 9,23 & 90,77 \\
\hline 30 & 0,6 & 355 & 36,41 & 45,64 & 54,36 \\
\hline 50 & 0,3 & 230 & 23,59 & 69 , & 30,77 \\
\hline 100 & 0,15 & 210 & 21,54 & 90,77 & 9,23 \\
\hline Pan & Pan & 90 & 9,23 & 100,00 & 0,00 \\
\hline \multicolumn{2}{|c|}{ Jumlah } & 975 & 100 & 318,97 & \\
\hline
\end{tabular}

Sumber: Hasil Penelitian, (2020)

Diperoleh FM pasir sebesar 3,19 MBH. Syarat modulus halus butir untuk beton menurut ASTM yaitu 2,20\%-2,10\% MHB 2,5 s/d 3,0.

(e) Pengujian Kadar Air Agregat Halus

Tabel 9. Kelembapan Pasir

\begin{tabular}{lcc}
\hline \multicolumn{1}{c}{ Percobaan Nomor } & $I$ & $I I$ \\
\hline Berat Pasir (w1) - (gr) & $500 \mathrm{gr}$ & $500 \mathrm{gr}$ \\
Berat Pasir Oven (w2) - (gr) & $491 \mathrm{gr}$ & $494 \mathrm{gr}$ \\
Kelembapan Pasir : & $1,83 \%$ & $1,21 \%$ \\
(w1 - w2)/w2 x 100\% & & \\
\hline
\end{tabular}

Sumber: Hasil Penelitian, (2020)

Dari data tabel di atas diperoleh kelembapan pasir sebesar 1,52\%. Menurut ASTM C 566-89 yang diperbolehkan untuk kelembaban pasir sebesar dalam penggunaan beton adalah $<0,1 \%$.

(f) Pengujian Pasir Pada Kondisi SSD

Tabel 10. Berat Jenis Pasir

\begin{tabular}{|c|c|c|}
\hline Percobaan Nomor & $I$ & II \\
\hline $\begin{array}{l}\text { Berat Labu + Pasir Basah } \\
\text { (w1)-(gr) }\end{array}$ & $883 \mathrm{gr}$ & $879 \mathrm{gr}$ \\
\hline Berat Pasir SSD (w2) - (gr) & $250 \mathrm{gr}$ & $250 \mathrm{gr}$ \\
\hline Berat Labu + Air (w2) $-(\mathrm{gr})$ & $725 \mathrm{gr}$ & $725 \mathrm{gr}$ \\
\hline
\end{tabular}


Kelembapan Pasir :

w2(w2 - w3) - (w1)

Sumber: Hasil Penelitian, (2020)

Dari data tabel di atas diperoleh berat jenis pasir sebesar 2,66 \%. Berat jenis pasir yang disyaratkan dalam ASTM C 128-78 yang digunakan campuran beton adalah yang berada dalam batas antara 2,4 sampai dengan 2,7 $\mathrm{gr} / \mathrm{dm}^{3}$.

(g) Pengujian Kadar Resapan Air

Tabel 11. Kadar Resapan Air

\begin{tabular}{lcc}
\hline \multicolumn{1}{c}{ Percobaan Nomor } & $I$ & $I I$ \\
\hline Berat Pasir SSD (gr) & $500 \mathrm{gr}$ & $500 \mathrm{gr}$ \\
Berat Pasir Oven (w1) - (gr) & $490 \mathrm{gr}$ & $489 \mathrm{gr}$ \\
Kadar Air Resapan : & $2,04 \%$ & $2,25 \%$ \\
$(500-\mathrm{w} 1) / \mathrm{w} 1$ x $100 \%$ & &
\end{tabular}

Sumber: Hasil Penelitian, (2020)

Dari tabel di atas diperoleh kadar air resapan pasir sebesar 2,14\%. Absorbsi (penyerapan air), syarat absorbsi menurut ASTM adalah 0,2\% $2,0 \%$.

(h) Pengujian Bobot Isi Rongga Udara dalam Pasir

Tabel 12. Berat Volume Pasir

\begin{tabular}{lccl}
\hline \multicolumn{1}{c}{ Jenis Percobaan } & $\begin{array}{c}\text { Kondisi } \\
\text { Biasa }\end{array}$ & $\begin{array}{c}\text { Dengan } \\
\text { Rojokan }\end{array}$ & $\begin{array}{l}\text { Dengan } \\
\text { Ketukan }\end{array}$ \\
\hline Berat Silinder (w1) & $11,73 \mathrm{~kg}$ & $11,73 \mathrm{~kg}$ & 11,73 \\
$-(\mathrm{kg})$ & & & $\mathrm{kg}$ \\
Berat Silinder + & $18,35 \mathrm{~kg}$ & $19,74 \mathrm{~kg}$ & 19,48 \\
$\begin{array}{l}\text { Pasir (w2) - (kg) } \\
\text { Berat Pasir (w2 - }\end{array}$ & $6,64 \mathrm{~kg}$ & $8,035 \mathrm{~kg}$ & $\mathrm{~kg}$ \\
w1) - (kg) & & & $\mathrm{kg}$ \\
Volume Silinder (v) & $5,299 \mathrm{lt}$ & $5,299 \mathrm{lt}$ & $5,299 \mathrm{lt}$ \\
$-($ liter) & & & \\
Berat Volume (w2 - & $\begin{array}{l}1,249 \\
\text { w1)/v }\end{array}$ & 1,512 & 1,462 \\
Sumber: Hasil Penelitian, (2020) & $\mathrm{kg} / \mathrm{lt}$ & $\mathrm{kg} / \mathrm{lt}$ \\
\hline
\end{tabular}

Dari tabel di atas diperoleh volume pasir sebesar 1,401 kg/liter, berat volume pasir spesifikasi agregat halus menurut ASTM C29 yaitu $1,6-1,9 \mathrm{~kg} / \mathrm{liter}$.

\subsection{Proses Pembuatan Benda Uji}

(a) Mix Design Bata Beton (Paving Block)

Perbandingan campuran material beton pada penelitian ini yaitu $1 \mathrm{PC}: 2 \mathrm{PS}, 1 \mathrm{PC}: 3 \mathrm{PS}$ dan 1 PC : 4 PS. Maka dapat ditentukan porsi dari masing-masing material yang dibutuhkan untuk mendapatkan hasil campuran beton yang sesuai dengan tujuan penelitian ini. Campuran dibawah ini merupakan campuran untuk benda uji pada penelitian ini.

(1) Mix Design Paving Block Normal

Tabel 13. Kebutuhan Semen Portland untuk 4 Buah (Paving Block) Normal

\begin{tabular}{ccccc}
\hline Campuran & Semen & Satuan & Semen & Satuan \\
\hline 1Pc $: 2 \mathrm{Ps}$ & 0,0002408 & $\mathrm{~m}^{3}$ & 5,02 & $\mathrm{Kg}$ \\
$1 \mathrm{Pc}: 3 \mathrm{Ps}$ & 0,0001806 & $\mathrm{~m}^{3}$ & 3,76 & $\mathrm{Kg}$ \\
\hline
\end{tabular}

\begin{tabular}{crrrr}
\hline 1Pc : 4Ps & 0,0001444 & $\mathrm{~m}^{3}$ & 3,01 & $\mathrm{~kg}$ \\
\hline Sumber: Hasil Analisa, $(2020)$ & &
\end{tabular}

Tabel 14. Kebutuhan Pasir untuk 4 Buah (Paving Block) Normal

\begin{tabular}{ccccc}
\hline Campuran & Pasir & Satuan & Pasir & Satuan \\
\hline 1Pc $:$ 2Ps & 0,0004816 & $\mathrm{~m}^{3}$ & 7,22 & $\mathrm{Kg}$ \\
1Pc $:$ 3Ps & 0,0005418 & $\mathrm{~m}^{3}$ & 8,13 & $\mathrm{Kg}$ \\
1Pc $:$ 4Ps & 0,0005779 & $\mathrm{~m}^{3}$ & 8,67 & $\mathrm{~kg}$ \\
\hline
\end{tabular}

Sumber: Hasil Analisa, (2020)

(2) Mix Design Paving Block Subtitusi LUSI $40 \%$

Tabel 15. Kebutuhan Pasir untuk 4 Buah (Paving Block) Subtitusi

\begin{tabular}{ccccc}
\hline Campuran & Pasir & Satuan & Pasir & Satuan \\
\hline 1Pc $:$ Ps & 0,0002889 & $\mathrm{~m}^{3}$ & 4,33 & $\mathrm{Kg}$ \\
1Pc $:$ 3Ps & 0,0003251 & $\mathrm{~m}^{3}$ & 4,88 & $\mathrm{Kg}$ \\
1Pc $: 4 \mathrm{Ps}$ & 0,0003468 & $\mathrm{~m}^{3}$ & 5,20 & $\mathrm{~kg}$
\end{tabular}

Sumber: Hasil Analisa, (2020)

Tabel 16. Kebutuhan LUSI untuk 4 buah (Paving Block)

\begin{tabular}{ccccc}
\hline Campuran & LUSI & Satuan & LUSI & Satuan \\
\hline 1Pc : 2Ps & 0,0001926 & $\mathrm{~m}^{3}$ & 2,89 & $\mathrm{Kg}$ \\
1Pc : 3Ps & 0,0002167 & $\mathrm{~m}^{3}$ & 3,25 & $\mathrm{Kg}$ \\
1Pc : 4Ps & 0,0002312 & $\mathrm{~m}^{3}$ & 3,47 & $\mathrm{~kg}$ \\
\hline
\end{tabular}

Sumber: Hasil Analisa, (2020)

Perhitungan air menggunakan ketentuan dari nilai FAS pada buku karangan Tjokroadimuljo. K, 1986 dalam penelitian terdahulu dari Dewi, Andi Rosita tahun 2014, yaitu sebesar 0,4 dengan sepesifikasi beton diluar bangunan tidak terlindungi dari hujan dan terik matahari langsung, yang berdasarkan SK-SNI didapat kebutuhan air untuk bahan susun $1 \mathrm{~m}^{3}$ paving block sebagai berikut:

Tabel 17. Kebutuhan Air untuk 4 Buah Paving Block

\begin{tabular}{cccc}
\hline No & Campuran & Kebutuhan Air & Satuan \\
\hline 1 & 1Pc $: 2 \mathrm{Ps}$ & 0,0001926 & liter \\
2 & 1Pc $:$ PPs & 0,0002167 & liter \\
3 & 1Pc : 4Ps & 0,0002312 & liter \\
\hline
\end{tabular}

Sumber: Hasil Analisa, (2020)

Perhitungan mix design paving block direncanakan dengan komposisi sebagai berikut 1 PC : 2 PS, 1 PC : 3 PS dan 1 PC : 4 PS. Pembuatan paving block tidak membutuhkan air terlalu banyak, apabila penambahan air terlalu banyak, maka campuran paving block tidak dapat dicetak.

\subsection{Pengujian Benda Uji}

Proses pengujian benda uji dilakukan pada umur 7 hari. Adapun beberapa tahapan dalam pengujian benda uji yaitu:

(a) Pengukuran Benda Uji

Pengukuran benda uji dilakukan untuk memastikan ukuran benda uji sesuai dengan yang telah direncanakan, pengukuran dilakukan di 
semua sisi benda uji paving block. Data dimensi benda uji paving block hasil pengukuran adalah sebagai berikut, Panjang $(p)=20,5 \mathrm{~cm}$, Lebar (1) $=10,5 \mathrm{~cm}$, Tebal $(\mathrm{t})=8 \mathrm{~cm}$, Luas $(\mathrm{L})=215,25$ $\mathrm{cm}^{2}$.

Semua benda uji berukuran sama karena menggunakan cetakan yang sama dengan data seperti yang telah dituliskan diatas. Panjang paving block mengikuti standart ukuran dari pabrik, yaitu $20,5 \mathrm{~cm}$.

(b) Penimbangan Benda Uji

Penimbangan benda uji dilakukan sebelum pengujian kuat tekan pada benda uji, pengujian benda uji dilakukan untuk mengetahui berat setiap benda uji dan data tersebut digunakan sebagai data penelitian. Berikut ini adalah data hasil penimbangan benda uji paving block.

Tabel 18. Berat Benda Uji Paving Block Normal dan Subtitusi LUSI

\begin{tabular}{|c|c|c|c|}
\hline No & & $d a U j i$ & Rata-rata $(\mathrm{Kg})$ \\
\hline 1 & \multirow{3}{*}{$\begin{array}{l}\bar{\Xi} \\
\text { हू } \\
\text { Z }\end{array}$} & $1 \mathrm{Pc}: 2 \mathrm{Ps}$ & 2,90 \\
\hline 2 & & 1Pc : 3Ps & 2,98 \\
\hline 3 & & 1Pc : 4Ps & 3,06 \\
\hline 4 & \multirow{3}{*}{ 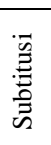 } & $1 \mathrm{Pc}: 2 \mathrm{Ps}$ & 2,91 \\
\hline 5 & & 1Pc : 3Ps & 3,01 \\
\hline 6 & & 1Pc : 4Ps & 3,03 \\
\hline
\end{tabular}

Sumber: Hasil Analisa, (2020)

\subsection{Analisa Data Hasil Pengujian Kuat Tekan}

Analisa data kuat tekan didapat dari hasil pengujian kuat tekan paving block dengan campuran normal atau dengan yang sudah disubtitusi LUSI sebesar $40 \%$ dari nilai agregat halus.

Kuat Tekan $=$ P/A

Keterangan: $\mathrm{P}=$ Tekanan Hancur (ton)

$$
\mathrm{A}=\text { Luas Penampang (terkena tekanan) }
$$

Sumber: SNI 03-0691-1996 : Paving Block

tahap selanjutnya adalah dilakukan perhitungan nilai kuat tekan rata-rata dari masing-masing proporsi campuran dari masing-masing benda uji menggunakan rumus sebagai berikut: Kuat tekan rata-rata $=\frac{\text { Kuat Tekan } B U(A+B+C)}{\text { Jumlah Benda } U j i}$

Tabel 19. Hasil Pengujian Kuat Tekan Paving Block Umur 7 Hari

\begin{tabular}{|c|c|c|c|c|}
\hline No & \multicolumn{2}{|c|}{ Benda Uji } & $\begin{array}{c}\text { Tekanan } \\
\text { Hancur Rata- }\end{array}$ & $\begin{array}{c}\text { Kuat Tekan } \\
\text { Rata-rata }\end{array}$ \\
\hline 1 & \multirow{3}{*}{$\begin{array}{l}\text { శే } \\
\text { Z } \\
\text { Z }\end{array}$} & $1 \mathrm{Pc}: 2 \mathrm{Ps}$ & 39,25 & 279,86 \\
\hline 2 & & 1Pc : 3Ps & 36,25 & 258,47 \\
\hline 3 & & 1Pc : 4Ps & 32,19 & 229,95 \\
\hline 4 & \multirow{3}{*}{ 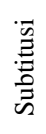 } & $1 \mathrm{Pc}: 2 \mathrm{Ps}$ & 26,50 & 188,95 \\
\hline 5 & & 1Pc : 3Ps & 15,00 & 106,95 \\
\hline 6 & & 1Pc : 4Ps & 13,50 & 96,26 \\
\hline
\end{tabular}

Sumber: Hasil Analisa, (2020)
Setelah didapatkan hasil dari uji kuat tekan paving block maka tahap selanjutnya adalah proses analisa dari umur 7 hari ke umur 28 hari. Adapun nilai koefisian hari dari konversi umur 7 hari ke umur 28 hari adalah sebagai berikut:

Tabel 20. Perbandingan Koefisien Hari Kuat Tekan Paving Block

\begin{tabular}{lcccc}
\hline Umur Beton (Hari) & 7 & 14 & 21 & 28 \\
\hline Semen Portland Biasa & 0,65 & 0,88 & 0,95 & 1,00 \\
$\begin{array}{l}\text { Semen Portland dengan } \\
\text { kekuatan awal tinggi }\end{array}$ & 0,75 & 0,90 & 0,95 & 1,00 \\
\hline Suta
\end{tabular}

Sumber: Pradana, (2019)

Dari tabel diatas, maka dapat dibaca untuk nilai koefisien hari kuat tekan pada umur 7 hari adalah 0,65 sedangkan pada umur 28 hari adalah 1,00 maka untuk perhitungan didapatkan persamaan sebagai berikut:

Nilai konversi $=\frac{\text { Kuat Tekan } \mathrm{x} 1}{0,65}$

Sebagai contoh benda uji normal dengan kuat tekan $279,86 \mathrm{~kg} / \mathrm{cm}^{2}$

Nilai konversi $=\frac{279,86 \times 1}{0,65}=430,55 \mathrm{~kg} / \mathrm{cm}^{2}$

Berikut ini adalah nilai hasil konversi kuat tekan benda uji pada umur 7 hari ke umur 28 hari, sebagai berikut:

Tabel 21. Hasil konversi Nilai Rata-rata Kuat Tekan Paving Block Normal Umur 7 Hari ke Umur 28 Hari

\begin{tabular}{|c|c|c|c|c|}
\hline \multirow{2}{*}{$N o$} & & \multirow{2}{*}{ Benda Uji } & \multicolumn{2}{|c|}{ Kuat Tekan $\left(\mathrm{kg} / \mathrm{cm}^{2}\right)$} \\
\hline & & & 7 Hari & 28 Hari \\
\hline 1 & \multirow{3}{*}{$\begin{array}{l}\bar{\Xi} \\
\text { ह̃ } \\
\text { z }\end{array}$} & $1 \mathrm{Pc}: 2 \mathrm{Ps}$ & 279,86 & 430,55 \\
\hline 2 & & $1 \mathrm{Pc}: 3 \mathrm{Ps}$ & 258,47 & 397,64 \\
\hline 3 & & $1 \mathrm{Pc}: 4 \mathrm{Ps}$ & 229,47 & 353,76 \\
\hline 4 & \multirow{3}{*}{$\begin{array}{l}\overline{\hat{0}} \\
. \bar{E} \\
\overline{\bar{n}}\end{array}$} & $1 \mathrm{Pc}: 2 \mathrm{Ps}$ & 188,95 & 290,69 \\
\hline 5 & & 1Pc : 3Ps & 106,95 & 164,54 \\
\hline 6 & & 1Pc : 4Ps & 96,26 & 148,09 \\
\hline
\end{tabular}

Sumber: Hasil Analisa, (2020)

Dari nilai kuat tekan $\mathrm{kg} / \mathrm{cm}^{2}$ pada tabel dilakukan konversi ke satuan Mpa untuk menggolongkan standart kuat tekan pada SNI 03-0691-1996 dengan ketentuan perbandingan benda uji sebagai berikut:

Tabel 22. Perbandingan Kuat Tekan pada Berbagai Benda Uji

\begin{tabular}{|c|c|}
\hline Benda Uji & Perbandingan Kuat Tekan \\
\hline $\begin{array}{l}\text { Kubus } 15 \mathrm{~cm} \times 15 \mathrm{~cm} \times \\
15 \mathrm{~cm}\end{array}$ & 1,00 \\
\hline $\begin{array}{l}\text { Kubus } 20 \mathrm{~cm} \times 20 \mathrm{~cm} \times \\
20 \mathrm{~cm}\end{array}$ & 0,95 \\
\hline Silinder $15 \mathrm{~cm}$ x $30 \mathrm{~cm}$ & 0,83 \\
\hline
\end{tabular}

Sumber: PBI 1971 N.1-2, 1971

Dimana:

$\begin{array}{ll}1 \mathrm{Mpa} & =1 \mathrm{~N} / \mathrm{mm}^{2} \\ 1 \mathrm{Kg} & =9,81 \mathrm{~N} \\ 1 \mathrm{~N} / \mathrm{mm}^{2} & =(1 / 9,81) \mathrm{kg} / \mathrm{mm}^{2} \\ & =(100 / 9,81) \mathrm{kg} / \mathrm{cm}^{2} \\ 1 \mathrm{Mpa} & =(100 / 9,81) \mathrm{kg} / \mathrm{cm}^{2} \\ 1 \mathrm{~kg} / \mathrm{cm}^{2} & =(9,81 / 100) \mathrm{Mpa}\end{array}$


Perhitungan pada benda uji normal dengan kuat tekan $430,55 \mathrm{~kg} / \mathrm{cm}^{2}$ kemudian dikonversi ke slinder $15 \mathrm{~cm} \times 30 \mathrm{~cm} \quad=430,55 \times 0,83$

$$
=357,36 \mathrm{~kg} / \mathrm{cm}^{2}
$$

Konversi satuan ke Mpa $=357,36$ × 9,81/ 100 $=35,06 \mathrm{Mpa}$

Tabel 23. Hasil Konversi Rata-rata Kuat Tekan dari $\mathrm{Kg} / \mathrm{cm}^{2}$ ke Mpa

\begin{tabular}{|c|c|c|c|c|}
\hline \multirow{2}{*}{ No } & & \multirow{2}{*}{ Benda Uji } & \multicolumn{2}{|c|}{ Kuat Tekan } \\
\hline & & & $\mathrm{kg} / \mathrm{cm}^{2}$ & $M P a$ \\
\hline 1 & \multirow{3}{*}{$\begin{array}{l}\bar{\sigma} \\
\text { : } \\
\text { z }\end{array}$} & $1 \mathrm{Pc}: 2 \mathrm{Ps}$ & 430,55 & 35,06 \\
\hline 2 & & 1Pc : 3Ps & 397,64 & 32,38 \\
\hline 3 & & 1Pc : 4Ps & 353,76 & 28,80 \\
\hline 4 & \multirow{3}{*}{$\begin{array}{l}\bar{y} \\
\bar{E} \\
\overline{0} \\
\bar{n}\end{array}$} & $1 \mathrm{Pc}: 2 \mathrm{Ps}$ & 290,69 & 23,67 \\
\hline 5 & & $1 \mathrm{Pc}: 3 \mathrm{Ps}$ & 164,54 & 13,40 \\
\hline 6 & & 1Pc : 4Ps & 148,09 & 12,06 \\
\hline
\end{tabular}

Sumber: Hasil Analisa, (2020)

\subsection{Hasil Uji Kuat Tekan Pemanfaatan LUSI}

Hasil penelitian kuat tekan paving block dengan komposisi campuran $1 \mathrm{Pc}: 2 \mathrm{Ps}, 1 \mathrm{Pc}: 3 \mathrm{Ps}$ dan $1 \mathrm{Pc}: 2 \mathrm{Ps}$ dengan proporsi normal dengan dibandingkan dengan subtitusi LUSI sebesar $40 \%$ dari nilai agregat halus. Berikut ini adalah hasil analisa perhitungan kuat tekan paving block setelah dilakukan konversi ke 28 hari.

Tabel 24. Hasil Pengujian Kuat Tekan Paving Block

\begin{tabular}{|c|c|c|c|}
\hline $\mathrm{No}$ & & ida Uji & Kuat Tekan (Mpa) \\
\hline 1 & \multirow{3}{*}{ 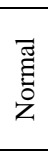 } & $1 \mathrm{Pc}: 2 \mathrm{Ps}$ & 35,06 \\
\hline 2 & & 1Pc : 3Ps & 32,38 \\
\hline 3 & & 1Pc : 4Ps & 28,80 \\
\hline 4 & \multirow{3}{*}{ 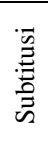 } & $1 \mathrm{Pc}: 2 \mathrm{Ps}$ & 23,67 \\
\hline 5 & & $1 \mathrm{Pc}: 3 \mathrm{Ps}$ & 13,40 \\
\hline 6 & & 1Pc : 4Ps & 12,06 \\
\hline
\end{tabular}

Sumber: Hasil Analisa, (2020)

Berikut ini adalah grafik perbandingan hasil kuat tekan paving block normal dan paving block subtitusi LUSI yang sudah dilakukan konversi dari umur 7 hari ke umur 28 hari.

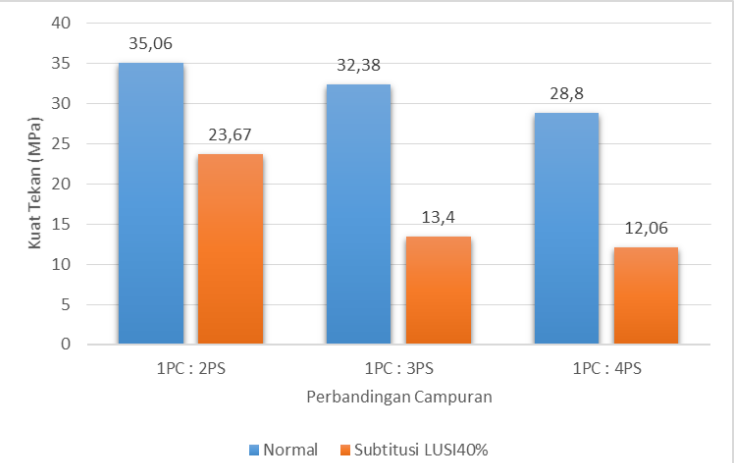

Gambar 2. Perbandingan Kuat Tekan Paving Block Normal dengan Paving Block Subtitusi LUSI $40 \%$

\subsection{Penggolongan Mutu Paving Block}

Penggolongam mutu paving block Hasil analisa data selanjutnya digolongkan dalam standart mutu kuat tekan paving block dengan mengacu SNI 030691-1996:Paving Block. Berikut ini adalah penggolongan mutu kuat tekan paving block.

Tabel 25. Penggolongan Mutu Standart Kuat Tekan Paving Block

\begin{tabular}{|c|c|c|c|c|}
\hline $\mathrm{No}$ & \multicolumn{2}{|c|}{ Benda Uji } & Kuat Tekan (Mpa) & Mutu \\
\hline 1 & \multirow{3}{*}{ 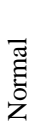 } & $1 \mathrm{Pc}: 2 \mathrm{Ps}$ & 35,06 & $\bar{A}$ \\
\hline 2 & & 1Pc : 3Ps & 32,38 & B \\
\hline 3 & & 1Pc : 4Ps & 28,80 & B \\
\hline 4 & \multirow{3}{*}{ 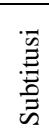 } & $1 \mathrm{Pc}: 2 \mathrm{Ps}$ & 23,67 & B \\
\hline 5 & & 1Pc : 3Ps & 13,40 & $\mathrm{C}$ \\
\hline 6 & & 1Pc : 4Ps & 12,06 & $\mathrm{C}$ \\
\hline
\end{tabular}

Sumber: Hasil Analisa, (2020)

Berikut ini adalah perbandingan mutu paving block komposisi campuran normal dengan subtitusi LUSI $40 \%$.

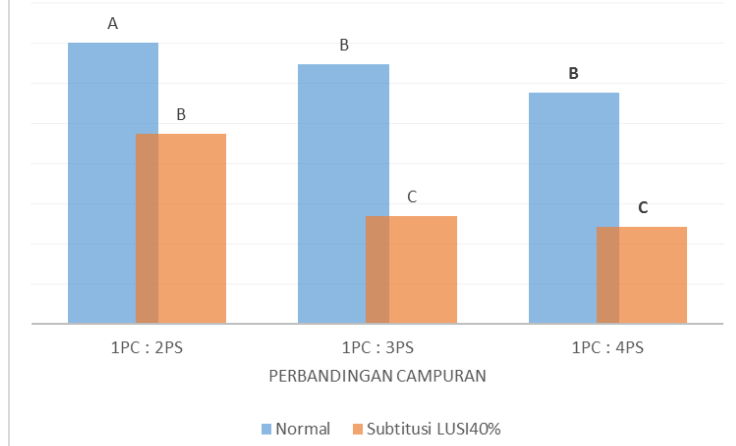

Gambar 3. Perbandingan Mutu Paving Block Normal dengan Subtitusi LUSI $40 \%$

\section{KESIMPULAN}

Berdasarkan hasil pengujian, analisis data dan pembahasan yang telah diuraikan sebelumnya, maka dapat ditarik kesimpulan:

(a) proses pemanfaatan LUSI sebelum digunakan sebagai bahan subtitusi agregat halus terdapat beberapa tahap, yaitu tahap tahap pengambilan bahan, tahap pengeringan bahan dan tahap pencampuran bahan.

(b) Kuat tekan yang dihasilkan setelah agregat halus disubtitusi dengan LUSI mengalami penurunan pada kuat tekan, dengan nilai prosentase penurunan berurutan sebesar 32\%, 59\% dan $58 \%$. Paving Block dengan mix design normal 1Pc:2Ps tergolong dalam mutu "A" dan untuk campuran 1Pc:3Ps dan 1Pc:4Ps tergolong dalam mutu "B", sedangkan untuk paving block subtitusi LUSI pada campuran 1Pc:2Ps Tergolong dalam mutu "B" dan untuk campuran 1Pc:3Ps dan 1Pc:4Ps tergolong dalam mutu " $\mathrm{C}$ ".

Berdasarkan hasil penelitian dan evaluasi yang telah dilakukan pada penelitian ini, pada pelaksanaan maupun hasil yang diperoleh, maka dalam hal ini akan diberikan saran-saran untuk 
memperbaiki penelitian selanjutnya yang sejenis, yaitu:

(a) perlu adanya penelitian lanjut tentang kuat tekan paving block dengan subtitusi LUSI yang berbeda untuk mendapatkan nilai kuat tekan yang lebih optimal.

(b) Perlu adanya penelitian lanjut tentang metode penggunaan LUSI sebagai subtitusi agregat agar lebih efisien digunakan sebagai subtitusi agregat dalam pembuatan paving block.

(c) Perlu adanya penelitian lanjut tentang penggunan LUSI sebagai subtitusi semen dalam pembuatan paving block.

\section{PUSTAKA}

Asroni, Ali. 2010. Balok Pelat Beton Bertulang. Yogyakarta: Graha Ilmu.

BSNI. 2002. SNI 03-2847-2002. Tata Cara Perhitungan Struktur Beton untuk Bangunan Gedung. Jakarta: BSNI.

BSNI. 1996. SNI 03-0691-1996. Bata Beton (Paving Block). Jakarta: BSNI.

Ekaputri, J.J., dan Triwulan. 2014. Sodium sebagai Aktivator Fly Ash, Trass dan Lumpur Sidoarjo dalam Beton Geopolimer. Surabaya: Institut Teknologi Sepuluh Nopember.

Lasino. 2016. Solusi untuk LUSI Lumpur Sidoarjo. Jakarta: CV. Cipta Dea Pustaka.

Pradana, Wijaya BP. 2019. Pengaruh Penambahan Serbuk Cangkang Kerang (Anadara Granosa) Terhadap Perubahan Kuat Tekan Bata Beton (Paving Block). Skripsi. Lamongan: Universitas Islam Lamongan.

Sugiharto, Bambang dan Lasion. 2018. LUSI Sebagai Material Konstruksi. Jakarta: PT Elex Media Komputindo. 